Nadwa : Jurnal Pendidikan Islam

Vol. 12, Nomor 1 Tahun 2018

Accredited by Ristekdikti based on Decree No. 51/E/KPT/2017

\title{
Upaya Pengembangan Kurikulum Prodi S.2 Manajemen Pendidikan Islam (MPI) UIN Walisongo Semarang
}

\author{
Muslih \\ Universitas Islam Negeri Walisongo Semarang \\ muslih@walisongo.ac.id
}

\begin{abstract}
This article presents a discussion of Curriculum Development Effort of S.2 Management of Islamic Education (MPI) UIN Walisongo Semarang especially related to input from users or ekesternal stakeholders, which include graduate and alumni users. Data collection methods used were open questionnaires, indepth interviews and documentation. The findings of the research mentioned that the effort of curriculum development of Study Program S.2 Management of Islamic Education UIN Walisongo Semarang has two strategies. First: a bottom up strategy that responsive to market needs with indicators that graduate users have been satisfied and reactive to the needs of the graduates themselves. While the second stretegi is top down, following the National Standards of Higher Education Curriculum based on National Qualifiers Framework Indonesia (KKNI). Therefore, it can be said that in the effort of curriculum development, a joint effort is made between stakeholders' inputs and government standards.

Keywords: Curriculum; Development; Graduate; Respond; and User;
\end{abstract}

\begin{abstract}
Abstrak
Artikel ini menyajikan pembahasan mengenai Upaya Pengembangan Kurikulum Prodi S.2 Manajemen Pendidikan Islam (MPI) UIN Walisongo Semarang khususnya yang berhubungan dengan masukan users atau stakehoders ektsternal yang meliputi pengguna lulusan dan alumni. Metode pengumpulan data yang digunakan adalah kuesioner terbuka, wawancara mendalam dan dokumentasi. Temuan penelitian menyebutkan bahwa Upaya pengembangan kurikulum Program Studi S.2 Manajemen Pendidikan Islam Pascasarjana UIN Walisongo Semarang telah menempuh dua strategi. Yaitu bottom up yang responsive terhadap kebutuhan pasar dengan indikator bahwa pengguna lulusan telah merasa puas dan responsive dengan kebutuhan lulusan itu sendiri. Sedangkan stretegi kedua dengan top down berdasarkan standart Nasional Kurikulum Pendidikan Tinggi barbasis Kerangka Kualifikasi Nasional Indonesia (KKNI). Sehingga dapat dikatakan bahwa dalam upaya pengembangan kurikulum, ditempuh upaya gabungan antara masukan stakeholders dan standar pemerintah.
\end{abstract}

Kata Kunci: Kurikulum, Pengembangan, Alumni, Respons, dan User.

IS \$N 1979-1739 (P) ; ISSN 2502-8057 (E).

C) 2018 Nadwa : Jurnal Pendidikan Islam | UIN Walisongo.

Accredited by Ristekdikti based on Decree Na. 51/E/KPT/2017

http:/joumal.walisongo.ac.id/index.php/nadwa 


\section{Pendahuluan}

Tantangan yang dihadapi oleh dunia pendidikan kita semakin hari semakin berat. Dikatakan demikian karena dunia pendidikan harus mampu merespons dan beradaptasi dengan tuntutan zaman yang terus berkembang dari waktu ke waktu, apalagi di era globalisasi seperti sekarang ini. Pendidikan dituntut untuk mampu menghasilkan lulusan yang dapat diterima oleh pasar. Oleh karenanya adalah logis kalau dikatakan bahwa perubahan yang terjadi di tengah masyarakat dan tuntutan di tempat kerja, mau tidak mau akan berkorelasi signifikan terhadap perlunya perubahan dan penyesuaian di dalam ranah pendidikan itu sendiri.

Laju perkembangan informasi dan teknologi yang terjadi saat ini juga harus diimbangi dengan adanya sumber daya manusia yang berkualitas. Untuk menciptakan sumber daya manusia yang berkualitas harus dipersiapkan terlebih dahulu pendidikan yang baik. Oleh karena itu pemerintah, sebagai pemegang otoritas yang memiliki kewenangan dalam mengatur regulasi, harus tampil di depan dalam hal peningkatan mutu pendidikan. Salah satu aspek penting dalam dunia pendidikan adalah kurikulum..1 Kurikulum berfungsi sebagai acuan bagi satuan pendidikan, baik itu pendidik maupun peserta didik. Oleh karenanya, keberadaannya menjadi sangat vital dalam rangka mewujudkan pendidikan yang berkualitas.

Artikel ini menyajikan pembahasan mengenai Upaya Pengembangan Kurikulum Prodi S.2 Manajemen Pendidikan Islam (MPI) UIN Walisongo Semarang khususnya yang berhubungan dengan masukan users atau stakehoders ektsrnal yang meliputi pengguna lulusan dan alumni. Dikarenakan program studi MPI ini merupakan prodi lanjutan dari program studi Pendidikan Islam, maka alumni dalam hal ini merupakan alumni Pendidikan Islam yang di dalamnya telah menerima sebagian mata kuliah peogram studi MPI.

Penelitian ini menggunakan pendekatan kualitatif, oleh karenanya dalam menganalisa data ia menerapkan metode deskriptif yaitu mengorganisasikan dan memilah-milah data, lalu

1 E. Mulyasa. 2006. Kurikulum Tingkat Satuan Pendidikan; Sebuah Panduan Praktis. Bandung: PT. Remaja Rosdakarya, h.4. 
mensintesiskan dan mencari pola-pola, kemudian menemukan apa yang penting dan layak dipelajari untuk kemudian memutuskan mana yang bisa diceritakan kepada orang lain.2 Metode penelitian kualitatif ini berdasarkan pada filsafat postpositivisme, yang digunakan untuk meneliti kondisi objek yang alamiah dimana peneliti berperan sebagai instrumen kunci, lalu teknik pengumpulan datanya bersifat induktif dan hasil penelitian lebih menekankan makna dari pada generalisasi. 3 Penggalian data dilakukan dengan teknik kuesioner terbuka dan wawancara mendalam (terhadap users dan alumni), serta dokumentasi (terhadap struktur kurikulum Prodi S2 MPI UIN Walisongo). Penentuan informan dalam penelitian ini menggunakan teknik purposive sampling, yakni menentukan sampel dengan pertimbangan tertentu yang dipandang dapat memberikan data secara maksimal, hal ini berlaku baik untuk users yang mempekerjakan alumni maupun terhadap alumni konsentrasi Pendidikan Islam program magister Pascasarjana UIN Walisongo Semarang.

\section{Kurikulum}

Istilah kurikulum dipahami oleh para ahli dengan banyak pengertian. Secara harfiah kurikulum berasal dari bahasa Latin "curriculum" yang berarti bahan pengajaran. Ada yang mengatakan bahwa kata tersebut berasal dari bahasa Perancis "courier" yang berarti berlari. 4 Ada juga pendapat yang mengatakan kurikulum berasal dari Bahasa Yunani "curir" yang berarti pelari, dan "curare" yang berarti tempat berpacu. Jadi, istilah kurikulum berasal dari dunia olahraga pada zaman Romawi Kuno di Yunani, yang berarti jarak yang harus ditempuh oleh pelari dari garis start sampai finish.5 Bisa diambil

2 Lexy Moleong. 2006. Metodologi Penelitian Kualitatif. Bandung: Remaja Rosdakarya, h.248.

3 Sugiyono. 2005. Metode Penelitian Pendidikan. Bandung, Alfabeta, h.1.

4 S. Nasution. 1991. Pengembangan Kurikulum. Cet. Ke-4, Bandung: Citra Aditya Bakti, h.1.

5 Hasan Langgulung. 1986. Manusia dan Pendidikan suatu Analisa Psikologi Pendidikan. Jakarta: Pustaka Al-Husna, h.176. 
pemahaman bahwa jarak yang harus ditempuh di sini maknanya adalah kurikulum dengan muatan isi dan materi pelajaran yang dijadikan jangka waktu yang harus ditempuh oleh siswa untuk memperoleh ijazah.

Dalam Kamus Bahasa Indonesia Kontemporer, kata "kurikulum" berarti; perangkat mata pelajaran yang diberikan pada lembaga pendidikan, atau perangkat mata kuliah bidang khusus.6 Dalam bahasa Arab, istilah yang sering digunakan untuk menyebut kurikulum adalah kata "manhaj" yang berarti jalan terang yang dilalui manusia pada berbagai bidang kehidupan. Sedangkan kurikulum pendidikan (manhaj al-dirāsah) dalam kamus Tarbiyah adalah seperangkat perencanaan dan media yang dijadikan acuan oleh lembaga pendidikan dalam mewujudkan tujuan-tujuan pendidikan.7

Menurut Abudin Nata, secara umum pengertian kurikulum dapat dibedakan menjadi dua bagian yaitu pengertian kurikulum secara sempit dan pengertian kurikulum secara luas.8 Termasuk dalam kategori pengertian kurikulum secara sempit adalah apa yang dikatakan oleh Crow and Crow (sebagaimana dikutip oleh Oemar Hamalik) yakni kurikulum adalah rancangan pengajaran atau sejumlah mata pelajaran yang disusun secara sistematis untuk menyelesaikan suatu program untuk memperoleh ijazah.9 Demikian pula dengan apa yang dinyatakan oleh Abdurrahman Salih yang berpendapat bahwa kurikulum adalah sejumlah mata pelajaran yang disiapkan berdasarkan rancangan yang sistematik dan koordinatif dalam rangka mencapai tujuan pendidikan yang direncanakan. 10

6 Peter Salim dan Yenny Salim. 1991. Kamus Bahasa Indonesia Kontemporer. Jakarta: Modern English Press, h.802.

7 Hasan Langgulung. 1987. Asas-Asas Pendidikan Islam. Jakarta: Pustaka Al-Husna, h.176.

8 Abudin Nata. 2005. Filsafat Pendidikan Islam. Jakarta: Gaya Media Pratama, h.122.

9 Oemar Hamalik. 1987. Pembinaan Pengembangan Kurikulum. Bandung: Pustaka Madina, h.2.

10 Abdurrahman Salih Abdullah. t.t. Educational Theory a Qur'anic Outlook. Makkah al-Mukarromah: Umm al-Qura University, h.123. 
Pengertian kurikulum secara sempit juga diungkapkan oleh Muhammad Ali Khalil yang menyatakan kurikulum sebagai seperangkat perencanaan dan media untuk mengantar lembaga pendidikan dalam mewujudkan tujuan pendidikan yang diinginkan.11 Omar Muhammad mengatakan bahwa kurikulum adalah jalan terang yang dilalui oleh pendidik atau guru latih dengan orang-orang yang dididik dan dilatihnya untuk mengembangkan pengetahuan, ketrampilan dan sikap mereka.12 Oemar Hamalik yang mengatakan kurikulum merupakan sejumlah mata pelajaran yang mesti ditempuh oleh peserta didik dalam rangka memperoleh ijazah. 13 Sedangkan Sukmadinata menyatakan "Kurikulum (curriculum) merupakan suatu rencana yang memberi pedoman atau pegangan dalam proses kegiatan belajar mengajar". 14 Jadi, dalam pengertian yang sempit kurikulum dapat dimaknai sebagai semua pelajaran baik teori maupun praktek yang diberikan kepada siswa-siswa selama mengikuti suatu proses pendidikan tertentu. Kurikulum dalam pengertian ini terbatas pada pemberian pengetahuan dan keterampilan kepada siswa untuk kepentingan mereka melanjutkan pelajaran maupun terjun ke dunia kerja.

Selain pengertian yang sempit sebagaimana disinggung di atas, kurikulum juga dapat dipahami dengan pengertian yang lebih luas. Termasuk dalam pengertian kurikulum dalam arti yang luas adalah pendapat yang menyatakan bahwa kurikulum tidak hanya sekedar berisi rencana pelajaran semata. Menurut Ahmad Tafsir, kurikulum tidak hanya sekedar berisi rencana pelajaran atau bidang studi, melainkan semua yang secara nyata terjadi dalam proses pendidikan di sekolah. 15 Menurut Hasan

11 Muhammad Ali Khalil. t.t. Qamus Tarbiyah, English-Arab. Beirut: Dar al-'Ilm al-Maliyyin, h.103.

12 Omar Muhammad al-Toumy al-Syaibany. 1979. Falsafah alTarbiyah al-Islamiyah. terj. Hasan Langgulung. Jakarta: Bulan Bintang, h.478.

13 Oemar Hamalik. 1978. Pembinaan Pengembangan Kurikulum. Bandung: Pustaka Madina, h.2.

14Nana S. Sukmadinata. 2008. Pengembangan Kurikulum: Teori dan Praktek. Remaja Rosdakarya: Bandung, h.5.

15 Ahmad Tafsir. 2010. Ilmu Pendidikan Islam Dalam Perspektif Islam. Bandung: Remaja Rosdakarya, h.53. 
Langgulung kurikulum adalah sejumlah pengalaman pendidikan, kebudayaan, sosial, olahraga, dan kesenian, baik yang berada di dalam maupun luar kelas yang dikelola oleh sekolah.16 Nasution memaparkan bahwa kurikulum merupakan suatu rencana yang disusun untuk melancarkan proses belajar mengajar di bawah bimbingan dan tanggung jawab sekolah atau lembaga pendidikan beserta staf pengajaran. Selanjutnya Nasution menjelaskan sejumlah ahli teori kurikulum yang berpendapat bahwa kurikulum bukan hanya meliputi semua kegiatan yang direncanakan melainkan juga peristiwa-peristiwa yang terjadi di bawah pengawasan sekolah. Jadi selain kegiatan kurikulum yang formal juga ada yang sering disebut kegiatan ko-kurikuler atau ekstra kurikuler. 17 Dengan pengertian ini maka pengaturan halaman sekolah, penempatan keranjang sampah atau ketatnya disiplin sekolah yang dijalankan ikut termasuk dalam cakupan kurikulum karena semuanya itu akan menghasilkan suatu yang tercermin pada lulusannya.18

Menurut SK Mendiknas No. 232/U/2000 tentang Pedoman Penyusunan Kurikulum Pendidikan Tinggi dan Penilaian Hasil Belajar Peserta Didik, kurikulum adalah "seperangkat rencana dan pengaturan mengenai isi maupun bahan kajian dan pelajaran serta cara penyampaian dan penilaian yang digunakan sebagai pedoman penyelenggaraan kegiatan belajar dan mengajar di perguruan tinggi". 19 Kurikulum adalah sebuah program yang disusun dan dilaksanakan untuk mencapai suatu tujuan pendidikan. Jadi dengan demikian, kurikulum bisa dipahami sebagai sebuah program yang berupa dokumen program dan pelaksanaan program. Bila dimaknai sebagai sebuah dokumen, kurikulum dirupakan dalam bentuk rincian matakuliah, silabus,

16 Hasan Langgulung. 1987. h.483-484.

17 S. Nasution. 1989. Kurikulum dan Pengajaran. Jakarta: Rineka Cipta, h.5.

18 Suharsimi Arikunto dan Lia Yuliana. 2012. Manajemen Pendidikan. Jakarta: Aditya Media, h.95.

19 Tim Penyusun. 2008. Buku Panduan Pengembangan Kurikulum Berbasis Kompetensi Pendidikan Tinggi (Sebuah alternatif penyusunan kurikulum). Jakarta: Direktorat Akademik Direktorat Jenderal Pendidikan Tinggi, h.5. 
rancangan pembelajaran, dan sistem evaluasi keberhasilan. Bila dimaknai sebagai sebagai sebuah pelaksanan program maka kurikulum adalah bentuk pembelajaran yang nyata-nyata dilakukan.20

Perubahan yang sangat cepat di semua sektor kehidupan khususnya dunia kerja, mendorong perguruan tinggi perlu membekali lulusannya dengan kemampuan adaptasi dan kreativitas agar dapat mengikuti perubahan dan perkembangan yang cepat tersebut, begitu pula dengan kurikulumnya.21 Dengan demikian kurikulum itu bersifat dinamis dan selalu harus menyesuaikan dengan perkembangan kebutuhan masyarakat. Oleh karena itu kurikulum selalu mengalami proses pengembangan yang berlangsung secara terus menerus.22

Peraturan Menteri Pendidikan dan Kebudayaan Republik Indonesia Nomor 49 Tahun 2014 tentang Standar Nasional Pendidikan Tinggi mendefinisikan kurikulum secara lebih spesifik karena menyebutkan program studi sebagai unit yang bertanggung jawab sebagai penyelenggara. Kurikulum di gambarkan sebagai seperangkat rencana dan pengaturan mengenai capaian pembelajaran lulusan, bahan kajian, proses, dan penilaian yang digunakan sebagai pedoman penyelenggaraan program studi. 23 Apabila dikaitkan dengan sistem pendidikan tinggi, maka kurikulum dapat berperan sebagai: 1) Sumber kebijakan manajemen pendidikan tinggi untuk menentukan arah penyelenggaraan pendidikannya; (2) Filosofi yang akan mewarnai terbentuknya masyarakat dan iklim akademik; (3) Patron atau pola pembelajaran, yang mencerminkan bahan kajian, cara penyampaian dan penilaian pembelajaran. (4) Atmosfer atau iklim yang terbentuk dari hasil interaksi manajerial perguruan

20 Tim Penyusun. 2008. h.5.

21 Tim Penyusun. 2008. h.7.

22 Wina Sanjaya. 2008. Kurikulum dan Pembelajaran, Teori dan Praktek Pengembangan Kurikulum Tingkat Satuan Pendidikan (KTSP). Jakarta: Kencana, h.32.

23 Tim Kurikulum dan Pembelajaran Direktorat Pembelajaran dan Kemahasiswaan. 2014. Buku Kurikulum Pendidikan Tinggi. Jakarta: Direktorat Pembelajaran dan Kemahasiswaan Direktorat Jenderal Pendidikan Tinggi Kementerian Pendidikan dan Kebudayaan, h.7. 
tinggi dalam mencapai tujuan pembelajarannya; (5) Rujukan kualitas dari proses penjaminan mutu; serta (6) ukuran keberhasilan perguruan tinggi dalam menghasilkan lulusan yang bermanfaat bagi masyarakat. Dari penjelasan ini, nampak bahwa kurikulum tidak hanya berarti sebagai suatu dokumen saja, namun merupakan suatu rangkaian proses yang sangat krusial dalam pendidikan. 24 Kurikulum menempati posisi yang sangat penting dalam dunia pendidikan, selain pendidik dan peserta didik. Karena kurikulum tersebut akan menentukan ke arah mana dan mau jadi apa lulusan yang menempuh jenjang pendidikan tersebut.

\section{Kurikulum Pendidikan Tinggi di Indonesia}

Sejarah kurikulum pendidikan tinggi di Indonesia telah mengalami beberapa kali perubahan. Perubahan kurikulum pendidikan tinggi tersebut diawali pada tahun 1994 dengan dikeluarkannya Keputusan Menteri Pendidikan dan Kebudayaan RI Nomor 056/U/1994 tentang Pedoman Penyusunan Kurikulum Perguruan Tinggi dan Penilaian Hasil Belajar Mahasiswa, dimana kurikulum tersebut mengutamakan ketercapaian penguasaan IPTEKS. Oleh arena itu ia disebut sebagai Kurikulum Berbasis Isi (KBI). Di dalam kurikulum model ini ditetapkan mata kuliah wajib nasional pada program studi yang ada. Lalu, pada tahun 2000 Indonesia merekonstruksi konsep kurikulumnya dari Kurikulum Berbasis Isi (KBI) menjadi Kurikulum Berbasis Kompetensi (KBK). Hal ini dilakukan atas saran dari UNESCO melalui concept yang disebut the four pillars of education, yakni learning to know, learning to do, learning to be, dan learning to live together. 25

Untuk mendekatkan pendidikan pada kondisi pasar kerja dan industri, maka kurikulum KBK ini mengutamakan pencapaian kompetensi. KBK ini terdiri atas kurikulum inti dan institusional yang mencakup kompetensi utama, kompetensi pendukung dan

24 Tim Kurikulum dan Pembelajaran Direktorat Pembelajaran dan Kemahasiswaan. 2014. h.7.

25 Tim Penyusun. 2016b. Panduan Penyusunan Kurikulum Universitas Syiah Kuala. Darussalam Banda Aceh: Universitas Syah Kuala, Kementerian Riset, Teknologi dan Pendidikan Tinggi, h.3-4. 
kompetensi lainnya. Di dalam implementasinya KBK memerlukan penetapan kompetensi utama melalui kesepakatan bersama antara kalangan perguruan tinggi, masyarakat profesi, dan pengguna lulusan. Sedangkan untuk kompetensi pendukung dan kompetensi lain, ditetapkan oleh perguruan tinggi itu sendiri. Selanjutnya, perkembangan global yang terjadi saat ini telah menuntut masyarakat internasional menuntut adanya pengakuan atas capaian pembelajaran di Indonesia untuk disetarakan secara internasional, pemerintah meresponsnya dengan mengeluarkan perpres tentang Kerangka Kualifikasi Nasional Indonesia (KKNI) pada tahun 2012. Maka sejak tahun ini, kurikulum di perguruan tinggi di Indonesia mengalami pergeseran dengan memberikan ukuran penyetaraan capaian pembelajarannya. Kurikulum ini masih mendasarkan pada pencapaian kemampuan yang telah disetarakan untuk menjaga mutu lulusannya. Kurikulum ini dikenal dengan nama Kurikulum Pendidikan Tinggi (KPT). 26

Sebuah kurikulum dapat mengalami perubahan apabila terdapat pendirian baru mengenai proses belajar, sehingga timbul bentuk-bentuk kurikulum seperti activity atau experience curriculum, programmed instruction, pengajaran modul dan sebagainya. Perubahan dalam masyarakat, eksplorasi ilmu pengetahuan dan lain-lain mengharuskan adanya perubahan kurikulum. Perubahan-perubahan itu menyebabkan kurikulum yang berlaku tidak lagi relevan, dan ancaman serupa ini akan senantiasa dihadapi oleh setiap kurikulum, betapapun relevannya pada suatu saat. Oleh karena itu, perubahan kurikulum merupakan hal yang biasa. Bahkan kalau dipaksakan untuk mempertahankan kurikulum yang ada mungkin dampaknya akan merugikan peserta didik itu sendiri.27

\section{Respons users dan alumni Pascasarjana UIN Walisongo}

Dalam upaya perubahan kurikulum, suatu yang sangat penting adalah mempertimbangkan masukan dan respon dari stake holder eksternal terutama dari pengguna lulusan dan alumni. Mereka adalah pelanggan sesungguhnya dari jasa pendidikan dalam perspektif total quality manajemen. Oleh

26 Tim penyusun. 2016b. h.4.

27 S. Nasution. 2008. h.251-252). 
karena itu disini disampaikan bagaimana tanggapan dan respon pengguna lulusan dan alumni.

1. Respon user (pengguna lulusan)

Dari penelusuran dan pengumpulan data yang telah dilakukan di lapangan terhadap alumni Pascasarjana UIN Walisongo, bahwa respons mereka terhadap keberadaan para alumni Program Magister Pascasarjana UIN Walisongo Semarang di tempat mereka bekerja (menjadi guru) adalah positif. Hal itu terbukti, di SMAN 3 Semarang, dari wawancara yang peneliti lakukan terhadap kepala sekolah 28 dan Waka bidang akademik. 29 Saat penelitian ini dilakukan di SMAN 3 Semarang ada tiga orang guru Pendidikan Agama Islam (PAI) yang merupakan alumni Pascasarjana UIN Walisongo. Mereka adalah Hery Nugroho, Maskur dan Khairi. Kepala sekolah merespons positif terhadap mereka karena mereka bertiga dianggap mampu memberi pengaruh yang baik pada lingkungan kerja mereka.

Lebih lanjut kepala sekolah memberi penekanan kepada salah satu guru tersebut yakni Hery Nugroho sebagai sosok guru yang aktif, kreatif dan bisa menjadi inspirasi bagi temantemannya baik sesama guru PAI maupun guru dari mata pelajaran (mapel) lain. Dia mengatakan prestasi yang dicapai oleh Hery Nugroho telah membawa harum nama sekolah dengan menjadi guru berprestasi juara 1 tingkat provinsi untuk kategori guru PAI, dan juara 3 untuk kategori semua guru. Bahkan ia juga menjadi guru berprestasi tingkat nasional di Kemenag RI.

Selain itu, Hery Nugroho juga terpilih menjadi instruktur nasional untuk Kurikulum 2013 pada mapel PAI, dan bertugas melatih guru-guru di beberapa provinsi di Indonesia. Karena keseriusannya ia juga pernah terpilih dikirim ke Oxford University untuk mengikuti pelatihan bahasa Inggris selama 10 hari. Hal ini menurut kepala sekolah merupakan prestasi yang patut dibanggakan oleh pihak sekolah. Ini merupakan

28 Wawancara: Bambang Nianto Mulyo (Kepala Sekolah SMAN 3 Semarang).

29 Wawancara: Emmy Irianningsih (Waka Kurikulum SMAN 3 Semarang). 
kebanggaan bagi SMAN 3 Semarang yang berarti secara tidak langsung juga kebanggaan bagi Pascasarjana UIN Walisongo Semarang.

Adapun terhadap dua orang lagi alumni Pascasarjana UIN Walisongo (teman dari Hery Nurgroho yang jadi guru PAI di SMAN 3 Semarang), yakni Maskur dan Khairi, kepala sekolah juga mengapresiasi keduanya karena meskipun belum berprestasi seperti Hery Nugroho tetapi mereka juga aktif membina kegiatan keagamaan dan membimbing siswa dalam lomba-lomba keagamaan yang mewakili sekolah.

Ketika ditanyakan mengenai kompetensi dari para alumni Pascasarjana UIN Walisongo dalam menjalankan tugasnya sebagai guru dalam melakukan pembelajaran, dijelaskan oleh kepala sekolah SMAN 3 Semarang bahwa umumnya mereka bertiga memiliki kompetensi dasar yang bagus, baik dari segi kompetensi kepribadian, kompetensi sosial, kompetensi pedagogik, maupun kompetensi profesionalnya.

Termasuk dalam aspek kompetensi kepribadian adalah segi kedisiplinan, kejujuran, tanggung jawab dan percaya diri. Dalam hal kedisiplinan, dijelaskan oleh user (kepala sekolah) bahwa ketiga alumni pascasarjana UIN Walisongo tersebut (Hery Nugroho, Maskur dan Khairi) memiliki kedisiplinan yang sangat tinggi. Bisa dikatakan hampir tidak pernah mereka izin dari kelas, kecuali ada penugasan dinas dari sekolah yang bersamaan waktunya dengan jam mengajar mereka. Dalam hal kejujuran, para alumni Pascasarjana UIN Walisongo tersebut juga dinilai sangat jujur dalam menjalankan tugas dan kewajibannya. Hal itu juga merupakan karakter yang harus mereka tunjukkan dan contohkan kepada para murid mereka. Dalam hal tanggung jawab, ketiga alumni Pascasarjana UIN Walisongo tersebut dinilai sudah mengerti akan tanggung jawabnya sebagai pendidik dan menjadi suri tauladan bagi murid-muridnya. Adapun mengenai rasa percaya diri, mereka semua terlihat cukup percaya diri dengan statusnya sebagai guru PAI yang sejajar dengan guru-guru dari mata pelajaran lain.

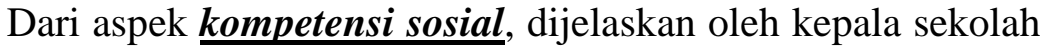
bahwa ketiga alumni Pascasarjana UIN Walisongo tersebut memiliki hubungan sosial atau pergaulan yang sangat baik 
dengan sesama guru maupun dengan tenaga kependidikan (staf) yang bekerja di sana, mereka juga memiliki hubungan baik dengan murid-muridnya. Alumni Pascasarjana UIN Walisongo yang menjadi guru di sana pun harus melakukan hal yang sama.

Untuk aspek kompetensi pedagogik atau kemampuan mengelola kelas dan mangatur pembelajaran, user (kepala sekolah) mengatakan bahwa pihaknya selalu memantau dan memonitor dengan cara sering masuk ke kelas-kelas. Berdasarkan pemantauan kepala sekolah mereka bertiga (alumni Pascasarjana UIN Walisongo) tersebut dinilai mampu melaksanakan pembelajaran yang PAIKEM (Pembelajaran Aktif Inovatif, kreatif, efektif dan menyenagkan) serta menggunakan alat-alat atau media pembelajaran digital dan komputer. Dari ketiganya yang paling menonjol dalam hal penggunaan IT dalam pembelajaran adalah Hery Nugroho. Sedangkan dua yang lainnya sudah bisa beradaptasi dengan IT dan komputer namun masih perlu ditingkatkan lagi sesuai dengan tuntutan para siswa.

Dari aspek kompetensi profesional (penguasaan terhadap materi atau bahan-bahan pelajaran yang harus disampaikan kepada para siswa), dijelaskan oleh kepala sekolah bahwa sebenarnya standar sebagai guru PAI sudah terpenuhi. Namun dihimbau untuk tetap selalu meningkatkan kapasitas dan kompetensinya dengan cara selalu membaca dan menambah wawasan serta meng-update dan meng-upgrade pengetahuannya supaya selalu mampu memberi penjelasan yang komprehensif terhadap para siswanya yang sangat kritis dan dinamis. Menurut analisis penulis, dari segi kompetensi profesional, para alumni Pascasarjana UIN Walisongo yang bekerja menjadi guru PAI di SMAN 3 Semarang sudah dibekali dengan sejumlah materi yang memadai ketika mereka kuliah. Tetapi apa yang disarankan oleh kepala sekolah tersebut benar adanya. Seorang guru sekalipun tidak boleh berhenti belajar dan menambah wawasan dan keilmuannya, karena perkembangan zaman yang sangat cepat maka guru dari mapel apapun harus selalu well-informed tentang materimateri yang berkenaan dengan pelajaran yang diampunya, tidak terkecuali guru-guru PAI. 


\section{Respon Alumni}

Adapun respons alumni terhadap pengaruh kurikulum dalam mendorong kesuksesan di dunia kerja mereka menyatakan bahwa :

Pertama, mereka ditanya mengenai kesesuaian antara mata kuliah-mata kuliah yang para alumni pelajari semasa kuliah S2 di Pascasarjana UIN Walisongo dengan tuntutan nyata di dunia kerja mereka saat ini. Mereka mengakui bahwa latar balakang keilmuannya mendukung atau memberi manfaat terhadap pekerjaannya sakarang ini, namun ada beberapa yang tidak matching atau tidak sesuai dengan pekerjaannya.

Sebagian alumni menyatakan bahwa kurikulum yang mereka alami masih terlalu tertumpu pada teori dan kurang applicable terutama bagi yang bekerja sebagai guru di SMA dimana mereka harus menerapkan Kurikulum 2013. Di dalam kurikulum 2013 guru harus mengajar, menilai peserta didik dengan pendekatan scientific. Hal semacam ini oleh para alumni Konsentrasi Pendidikan Islam Program Magister Pascasarjana UIN Walisongo yang bekerja sebagai guru dirasakan sebagai sesuatu yang baru dan belum dipelajari sewaktu kuliah S2 dulu. Seorang alumni bernama Hery Nugroho yang bekerja sebagai guru PAI di SMAN 3 Semarang, misalnya, ketika ditanyakan pendapatnya mengenai kesesuaian antara materi yang dia pelajari sewaktu belajar di Konsentrasi Pendidikan Islam Program Magister Pascasarjana UIN Walisongo dengan pekerjaan yang dia tekuni sekarang ini, ia mengatakan:

Saya merasakan sebagian sudah dapat saya terapkan, seperti matakuliah Ilmu Hadis, al-Qur'an, Evaluasi, Teknologi Pendidikan maupun Transformasi Global Pendidikan bisa saya manfaatkan dalam tugas saya sebagai guru Agama Islam di SMAN 3 Semarang, tapi ada beberapa hal yang perlu penyempuraan. Misalnya terkait dengan perkembangan kurikulum yang ada di sekolah, yakni yang terkait dengan penerapan kurikulum 2013. Apa yang saya peroleh dulu waktu kuliah di S2 banyak yang bersifat teoritis saja. Maka perlu ada kesesuaian dengan apa yang terjadi di sekolah, dan perlu adanya banyak praktik. Misalnya matakuliah Inovasi Pembelajaran perlu 
hal yang praktis lagi, inovasinya seperti apa dan bagaimana bentuknya. Alangkah baiknya mahasiswa yang kuliah di Pascasarjana UIN Walisongo diberi kesempatan untuk banyak praktik bukan hanya teori saja. Matakuliah Teknologi Pendidikan rasanya masih banyak teori dan masih kurang praktiknya, bagaimana mempraktikkan tekonologi pembelajarannya di kelas itu yang penting. 30

Respons yang sama juga dilontarkan oleh alumni Pascasarjana UIN Walisongo lainya yang bernama Ach.Tabrani, yang sekarang bekerja sebagai guru Agama di SMP al-Azhar Semarang. Ketika disinggung mengenai kesesuaian antara ilmu yang dia pelajari dulu sewaktu kuliah S2 dengan pekerjaannya sekarang, ia manjawab yang intinya adalah bahwa masalah materi keilmuannya sudah sesuai, namun masalah metodologi pengajaran harus semakin bervariasi dan perlu disesuaikan, dia menjelaskan:

Sekarang saya bekerja sebagai guru di SMPI al-Azhar di BSB Semarang, saya mengajar PAI, pendidikan al-Qur'an dan Bahasa Arab. Ada kesesuaian antara ilmu yang saya perlajari di Pascasarjana UIN Walisongo dengan pekerjaan sekarang saya sebagai guru. Di Al-Azhar pelajaran Akidah, Sejarah, Hadis dan Fiqih sudah digabung dalam PAI.31

Ia juga menambahkan bahwa guru harus kreatif dan bisa memilah materi karena menurutnya materi yang ia dapatkan dulu sewaktu kuliah di Pascasarjana UIN Walisongo lebih tinggi atau lebih luas cakupannya dari yang harus diajarkannya pada murid-muridnya di SMP, jadi guru harus mampu mengadaptasikan materinya. Untuk itu diperlukan kecerdasan dan kemandirian dari guru tersebut.

Sama halnya dengan pendapat dari alumni yang bekerja sebagai guru PAI di SMAN 3 Semarang, Ach.Tabrani menegaskan bahwa dengan kurikulum 2013, guru dituntut mengunakan scientific approach yang menggunakan $5 \mathrm{M}$ (mengamati, menanya, mengambil data, mengolah data, 
mengkonfirmasi). Guru tidak hanya sebagai fasilitator saja tapi juga sebagai pengarah bagi murid untuk mengamati apa yang ada sekitarnya sesuai dengan yang ditetapkan dalam silabus. Ia mengeluhkan bahwa hal ini tidak pernah dibahas ketika kuliah di S2 dulu, namun dituntut untuk melakukannya ketika bekerja sebagai guru yang harus menerapkan Kurikulum 2013. Manurut hemat penulis, ke depan hal ini (masalah scientific approach) ini harus menjadi perhatian di dalam kurikulum Pascasarjana UIN Walisongo.32

Menurut analisis penulis, apa yang dirasakan oleh para alumni tersebut memang ada benarnya. Mereka (yang jadi responden dalam penelitian ini) adalah para alumni yang sudah lulus dari Konsentrasi Pendidikan Islam Program Magister Pascasarjana UIN Walisongo Semarang pada 2012an, itu artinya mereka sudah lulus sebelum pemerintah Republik Indonesia menerapkan Kurikulum 2013. Sehingga di dalam struktur kurikulum Pascasarjana UIN Walisongo saat itu juga tidak mengarah kepada bagaimana mengantisipasi penerapan Kurikulum 2013. Meskipun demikian, informasi dari para alumni tersebut sangat bermanfaat, untuk bersikap antisipatif dengan apa yang akan terjadi ke depan di dalam menyusun atau membuat struktur kurikulum di Pascasarjana UIN Walisongo.

Kedua: Ketika ditanyakan pandangannya mengenai pengetahuan atau ketrampilan apa yang perlu ditingkatkan oleh para alumni konsentrasi Pendidikan Islam Program Magister Pascasarjana UIN Walisongo ketika menggeluti pekerjaanya sekarang ini?. Salah seorang alumni yang bekerja di SMAN 3 Semarang (Hery Nugroho) menjabarkan bahwa untuk aspek pengetahuan yang perlu ditingkatkan adalah dalam hal core (keilmuan keagamaan). Karena guru PAI di sekolah itu - sebagaimana yang pernah dikatakan oleh seorang direktur di kemenag - adalah menjadi mufti (pemberi fatwa) di sekolah masing-masing, dan karena sering ditanya masalah-masalah keagamaan, maka guru agama (PAI) harus memiliki wawasan dan pengetahuan keagamaan yang komprehensif. Oleh karena itu, menurutnya ilmu yang

32 Wawancara: Ach.Tabrani (Guru SMAN 3 Semarang). 
menjadi core keilmuannnya harus di-update terus supaya guru agama dapat memberi pencerahan dan menyampaikan Islam yang rahmatan lil alamin terutama menyikapi fenomena radikalisme di sekolah. Karena ada temuan dari pengawas sekolah bahwa ada beberapa guru agama yang pemahaman keagamaannya sempit, misalnya kalau tidak seperti apa yang dia katakan maka akan dianggap kafir. Maka ada kebijakan dari Kemterian Agama Republik Indonesia agar dikembangkan di sekolah-sekolah yaitu pembelajaran PAI yang ISRA (Islam Rahmatan lil Alamin). Untuk itu menurut Hery Nugroho pengelola pascasarjana UIN Walisongo harus connect dan memperhatikan hal ini.33

Mereka juga berpandangan bahwa perlunya pengkayaan kompetensi dan ketrampilan dalam penerapan metode pembelajaran mutakhir dan ketramplian di bidang penggunaan perangkat Informasi dan Teknologi (IT). Maka dari itu mereka mengusulkan agar pihak pengelola Progam Magister Pascarajana UIN Walisongo juga harus memperhatikan dan meningkatkan hal-hal tersebut. Disebutkan juga bahwa dalam aspek ketrampilan perlu pula di-update masalah metode supaya dapat menguatkan pembelajaran PAIKEM yang active learning dan joyfull. Terkait ketrampilan dalam mengajar guru harus mampu menerapkan beberapa metode, dan mau untuk "ijtihad" dalam hal penerapan pembelajaran yang active learning dan joyfull. Misalnya, bagaimana guru membuat inovasi dari teori Silberman dalam hal pembelajaran PAI yang menyenanglan. Selain itu bagaimana guru dapat dibekali dengan ketrampilan menulis. Pembuatan karya tulis sekarang sudah menjadi wajib bagi guru di SMAN 3 Semarang. Untuk kenaikan pangkat misalnya guru harus membuat PTK, artikel, maupun menulis buku. Maka menurutnya ke depan Pascasarjana UIN Walisongo juga harus memperhatikan hal-hal seperti ini supaya alumninya bisa diterima di tempat bekerjanya dengan baik.34

33 Wawancara: Hery Nugroho.

34 Wawancara: Hery Nugroho. 
Ach.Tabrani, alumni yang bekerja sebagai guru PAI di SMP Islam al-Azahar, menambahkan di SMP Islam al-Azhar BSB Semarang guru juga dituntut untuk mencetak siswa berprestasi, maka sebagai guru ia harus mampu membimbing tilawah, tahfid, pidato bahasa Indonesia dan bahasa Arab. Maka menurutnya perlu pembekalan bagi guru PAI untuk ketrampilan tersebut. Ketrampilan yang diperlukan oleh guru, menurut Ach.Tabrani, misalnya sebagai contoh di SMP Islam al-Azhar semua pembelajaran sudah pakai digital classroom, google classroom, dan guru harus menggunakan power point. Ia menyarankan ketrampilan dalam hal teknologi seperti itu perlu ditambahkan pada kurikulum di Pascasarjana UIN Walisongo ke depannya.35

Ketiga: Ketika ditanyakan mengenai perlu tidaknya perubahan dan penambahan matakuliah untuk kurikulum Pascasarjana UIN Walisongo, Hery Nugroho menyatakan pendapatnya bahwa ada beberapa matakuliah yang perlu ditambahkan. PAI perlu ada pendidikan karakter (penumbuhan budi pekerti) secara teoritik dan praktik (penerapan), karena bagi guru PAI ada titipan budi pekerti. Perlu ada semacam model/design pendidikan karakter. Selain itu juga perlu pengenalan pembuatan karya ilmiah. Metode pembelajaran perlu diajarkan yang betul-betul PAIKEM. 36 Sementara itu alumni yang lain (Maksur) menyarankan perlunya diperkuat studi Hadis dalam kurikulum di Program Magister Pascasarjana UIN Walisongo, karena menurutnya para siswa sering dapat informasi dari luar yang kurang tepat atau bahkan keliru, maka guru PAI harus lebih komprehensif lagi pengetahuannya. Bukan hanya matan Hadis saja tapi juga menyangkut fungsinya, karena sering kali guru mendengar pernyataan dari siswa yang itu tidak sesuai dengan Hadis. Maka guru agama (PAI) harus benar-benar mengetahui dengan lengkap hadis-hadis termasuk yang langka atau jarang didengar atau digunakan sekalipun.37

35 Wawancara: Ach.Tabrani (Guru SMPI al-Azhar Semarang).

36 Wawancara: Hery Nugroho.

37 Wawancara: Maskur (Guru SMAN 3 Semarang). 
Keempat, ketika dimintai saran, mereka ingin menambahkan bahwa mahasiswa perlu dibekali dengan masalah menajemen, dan cara evaluasi pada penerapan Kurikulum 2013. Sementara itu, alumni yang lain (Khairi) mengingatkan bahwa pihak Pascasarjana UIN Walisongo belum meng-cover masalah ekstra kurikuler. Menurut dia di sekolah manapun guru agama Islam (PAI) sering diberi tugas membimbing qiroah, marawis, pidato yang ini semakin sering dilombakan dan guru PAI harus membimbing siswa-siswanya dalam hal tersebut. Sementara itu ketika kuliah di pascarajana dulu hal semacam itu tidak pernah ia dapatkan. Makanya dia mengusulkan ke depan pihak Pascasarjana UIN Walisongo harus lebih peka lagi dan mau mangakomodasi dan membekali mahasiswanya dengan ketrampilan-ketrampilan semacam itu.38 Selain itu Ach.Tabrani yang bekerja sebagai guru di SMP Islam al-Azhar BSB Semarang memberi masukan atau saran perlunya ditambahkan metodologi pembelajaran PAI, karena sebagai guru agama Islam dia butuh varisasi supaya peserta didik tidak bosan. Ia juga memberi masukan bahwa karena sebagai guru ia mempunyai tugas membuat evaluasi yang cukup banyak seperti evaluasi untuk UTS, ulangan terpadu, ulangan harian, ulangan akhir, dan UKK, maka ia berharap supaya di Pascasarjana ada Mata kuliah Evaluasi yang mengajarkan dan menitikberatkan bagaimana membuat soal-soal yang benar. Yang diperlukan ini adalah lebih ke arah praktiknya untuk membuat soal yang benar bukan hanya teorinya saja. Untuk evaluasi, test tulis perlu dipertahankan, namun perlu ditambah portofolio (assigment).39

Dari berbagai pernyataan diatas dapat disimpulkan bahwa respon pengguna lulusan sudah merasa puas, sedangkan respon alumni meiputi : Satu, ingin memperolah teori dan praktek mengenai kurikulum 2013, kedua : peningkatan core keilmuan sesuai program studi, ketiga :; pendidikan budi pekerti dan studi hadits, keempat : masalah manajemen dan penambahan keterampilan ektra kurikuler.

38 Wawancara: Khairi (Guru SMAN 3 Semarang).

39 Wawancara: Ach.Tabrani. 


\section{Upaya Pengembangan Kurikulum Prodi S2 Manajemen Pendidikan Islam (MPI) Pascasarjana UIN Walisongo Semarang}

Respons dan pandangan yang disampaikan oleh users dan juga pandangan alumni tersebut terhadap kurikulum yang mereka alami memiliki implikasi dan konsekuensi yang berarti bagi pengembangan dan penerapan kurikulum baru pada Prodi S2 MPI Pascasarjana UIN Walisongo yang sedang beroperasi saat ini.

Secara ringkas, berikut ini disajikan kurikulum yang telah dirancang dan kemudian diterapkan oleh Prodi S2 MPI Pascasarjana UIN Walisongo untuk proses pembelajaran di tahun akademik 2016 dan seterusnya. Ini merupakan pengembangan dari kurikulum lama (konsentrasi Pendidikan Islam) yang kemudian disesuaikan dengan kebutuhan yang ada setelah bertransformasi menjadi sebuah prodi yang mandiri, yakni Prodi S2 MPI. Hal ini merupakan bentuk antisipasi agar alumni dari prodi ini dapat bersaing di tempat kerja mereka, sekaligus ini merupakan respons atas masukan dari beberapa alumni yang dimintai pendapat dan pandangannya dalam penelitian ini. Struktur kurikulum prodi S2 MPI dapat dilihat pada table

Struktur Kurikulum Prodi S2 MPI Pascasarjana UIN Walisongo 40

\begin{tabular}{lc}
\hline \multicolumn{1}{c}{ MATAKULIAH } & \\
\hline \multicolumn{1}{c}{ NAMA } & SKS \\
\hline - Studi al-Quran & 3 \\
- Studi al-Hadis & 3 \\
- Studi Peradaban Islam & $\underline{3}$ \\
& $\mathbf{9}$ \\
\hline -Metodologi Penelitian MPI & 3 \\
-Filsafat Ilmu & $\underline{3}$ \\
\hline
\end{tabular}

40 Sumber: Buku Profil dan Kompetensi Program Studi Program Magister Manajemen Pendidikan Islam (MPI) Pascasarjana UIN Walisongo). 


\begin{tabular}{lc}
-Manajemen Ketenagaan & 3 \\
-Manajemen kurikulum dan Evaluasi & 3 \\
-Manajemen Pemasaran, Manajemen Humas & 3 \\
dan Analisis Kebijakan & \\
-Manajemen Strategis dan Pengembangan & 3 \\
Mutu & 1 \\
-Kepemimpinan dan Perilaku Organisasi & 3 \\
-Supervisi Pendidikan Islam & 3 \\
-Karya Tulis Ilmiah/ Praktik Pengalaman & 3 \\
Lapangan & 3 \\
-Tesis & $\underline{6}$ \\
& $\mathbf{2 7}$ \\
\hline - Bimbingan Konseling & 3 \\
- Manajemen Madrasah Diniyah dan Pondok & 3 \\
Pesantren & \\
- Manajemen PAUD & 3 \\
- Manajemen Pendidikan Islam Dasar dan & 3 \\
$\quad$ Menegah & 3 \\
- Manajemen Perguruan Tinggi Islam & 3 \\
- Manajemen Pendidikan Islam Transformatif & \\
$\quad$ Perspektif Sensitif Gender, Multikultral, & 3 \\
Islam inklusif) &
\end{tabular}

Bahasa Arab 0

Bahasa Inggris 0

Pada tahap awalnya, Prodi S2 MPI Pascasarjana UIN Walisongo menyediakan 48 SKS dalam rancangan kurikulum yang akan diterapkan pada mahasiswanya. Perlu ditegaskan bahwa menurut Undang-Undang Nomor 12 Tahun 2012 tentang Pendidikan Tinggi, dinyatakan bahwa penyusunan kurikulum adalah hak perguruan tinggi, tetapi selanjutnya dinyatakan harus mengacu kepada standar nasional (Pasal 35 ayat 1).41 Sebenarnya Prodi S2 MPI memiliki hak dan kewenangan untuk merancang sendiri kurikulumnya, namun ada rambu-rambu yang harus dipatuhi yakni harus mengacu pada standar nasional. Kalau merujuk kepada ketentuan Kerangka Kualifikasi Nasional Indonesia (KKNI) maka kurikulum yang telah dirancang oleh prodi tersebut harus disesuaikan lagi baik muatan isi maupun

${ }_{41}$ Tim Penyusun. 2016. h.2. 
jumlah beban SKS-nya. Akhirnya melalui mekanisme sebuah workshop, kurikulum tersebut yang semula berjumlah 48 SKS ditinjau lagi dan disesuaikan dengan aturan KKNI yakni sekarang menjadi 42 SKS, sebagaimana dapat dilihat pada tabel dibawah ini merupakan upaya perubahan struktur kurikulum menjadi kurikulum 2016 (sesuai KKNI) Program Studi Managemen Pendidikan Islam (MPI) Pascasarjana UIN Walisongo 42

\begin{tabular}{|c|c|c|c|c|c|c|c|}
\hline \multirow[t]{2}{*}{ No } & \multirow[t]{2}{*}{ Kode } & \multirow[t]{2}{*}{ Nama Mata Kuliah } & \multirow[t]{2}{*}{ sks } & \multicolumn{4}{|c|}{ Semester } \\
\hline & & & & I & II & III & IV \\
\hline I & Ilmu Mul & isiplin (wajib) & & & & & \\
\hline 1 & PS 2101 & Studi Qur'an-Hadis & 3 & $X$ & & & \\
\hline 2 & PS 2102 & Filsafat Ilmu Keislaman & 3 & $\mathrm{X}$ & & & \\
\hline 3 & PS 2103 & Metodologi Penelitian & 3 & $\mathrm{X}$ & & & \\
\hline 4 & PS 2104 & $\begin{array}{l}\text { Pendekatan Ilmu-ilmu } \\
\text { Keislaman }\end{array}$ & 3 & & & $\mathrm{X}$ & \\
\hline 5 & PS 2105 & Bahasa Arab & 0 & $X$ & & & \\
\hline 6 & PS 2106 & Bahasa Inggris & 0 & $\mathrm{X}$ & & & \\
\hline II & Inti Keiln & In Program Studi (wajib) & & & & & \\
\hline 1 & MPI 2201 & Manajemen Ketenagaan & 3 & & $\mathrm{X}$ & & \\
\hline 2 & MPI 2202 & $\begin{array}{l}\text { Manajemen Kurikulum dan } \\
\text { Evaluasi }\end{array}$ & 3 & & $\mathrm{X}$ & & \\
\hline 3 & MPI 2203 & $\begin{array}{l}\text { Metodologi Pemasaran, } \\
\text { Manajemen Humas, dan } \\
\text { Analisis Kebijakan }\end{array}$ & 3 & & $\mathrm{X}$ & & \\
\hline 4 & MPI 2204 & $\begin{array}{l}\text { Manajemen Strategis dan } \\
\text { Pengembangan Mutu }\end{array}$ & 3 & & $\mathrm{X}$ & & \\
\hline 5 & MPI 2205 & $\begin{array}{l}\text { Kepemimpinan dan perilaku } \\
\text { organisasi }\end{array}$ & 3 & & $\mathrm{X}$ & & \\
\hline 6 & MPI 2206 & Karya Tulis Jurnal Ilmiah & 0 & & & $X$ & \\
\hline 7 & MPI 2207 & Seminar proposal & 3 & & & $\mathrm{X}$ & \\
\hline 8 & MPI 2208 & Tesis & 6 & & & & $\mathrm{X}$ \\
\hline III & Mata Kul & Pilihan & & & & & \\
\hline 1 & MPI 2401 & Matrikulasi MPI & 3 & & & $\mathrm{X}$ & \\
\hline 2 & MPI 2402 & Supervisi Pendidikan Islam & 3 & & & & \\
\hline 3 & MPI 2403 & Bimbingan Konseling & 3 & & & $\mathrm{X}$ & \\
\hline 4 & MPI 2404 & $\begin{array}{l}\text { Manajemen Madrasah Diniyah } \\
\text { dan Pesantren }\end{array}$ & 3 & & & & \\
\hline 5 & MPI 2405 & Manajemen PAUD & 3 & & & & \\
\hline
\end{tabular}

42 Sumber: Buku Company Profil Pascasarjana UIN Walisongo, 2016: 5 


\begin{tabular}{rrlr}
\hline 6 & MPI 2406 & $\begin{array}{l}\text { Manajemen Pendidikan Islam } \\
\text { Dasar dan Menengah }\end{array}$ & 3 \\
\hline $\mathbf{7}$ & MPI 2407 & $\begin{array}{l}\text { Manajemen Perguruan Tinggi } \\
\text { Islam }\end{array}$ & 3 \\
\hline $\mathbf{8}$ & MPI 2408 & $\begin{array}{l}\text { Manajemen Pendidikan Islam } \\
\text { Transformatif }\end{array}$ & 3 \\
\hline $\mathbf{9}$ & MPI 2409 & $\begin{array}{l}\text { Manajemen Perpustakaan dan } \\
\text { Laboran }\end{array}$ & 3 \\
\hline & & $\mathbf{4 2}$ \\
\hline
\end{tabular}

43

Paparan mengenai upaya pengembagan kurikulum yang terjadi pada Prodi S2 MPI Program Magister Pascasarjana UIN Walisongo Semarang pada tahun 2016 diatas sebagai

Strategi pertama yaitu merupakan respons terhadap dinamika dan perkembangan yang begitu cepat dalam dunia pendidikan. Respon stekeholders eksterna dari para pengguna lulusan merasa puas dengan keberadaan alumi Pascasarjana UIN Walisongo Semarang. Sedangkan tanggapan para lulusan meliputi empat hal utama yaitu (a)., ingin memperolah teori dan praktek mengenai kurikulum 2013 teah direspon dengan adanya mata kuliah Manajemen Kurikulum dan Evaluasi dengan kode MPI 2202 dengan beban 3 SKS. (b): masukan mengenai peningkatan core keilmuan sesuai program studi dan (c):; pendidikan budi pekerti dan studi hadits diwujud dalam mata kuliah Study Qur'an Hadits dan Filsafat Ilmu Keislaman dengan masing-masing 3 SKS, serta, $(d)$ : masalah manajemen dalam mata kulian Manajemen Madrasah Diniyah, Pesantren Manajemen Pendidikan Islam Dasar dan Menengah, Manajemen Pendidikan Islam Transformatif dengan masing-masing 3 SKS. Namun dalam hal keterampilan ektra kurikuler dan keterampilan IT nampaknya belum bisa tercover mengingat dalam menyusun kurikulum pihak Prodi S2 MPI juga harus memperhatikan peraturan dan batasan mengenai jumlah beban SKS yang boleh diterapkan kepada mahasiswanya. Pada struktur kurikulum Prodi S2 MPI Pascasarjana setelah disesuaikan dengan Kerangka Kualifikasi Nasional Indonesia (KKNI) sebagaimana terlihat

43 Tim Penyusun. 2016d. Company Profil Pascasarjana UIN Walisongo. Semarang: Pascasarjana UIN Walisongo, h.5. 
pada tabel 2, juga tidak ada mata kuliah khusus yang mengarah ke hal itu.

Stategi kedua: pengelola Prodi S2 MPI Pascasarjana UIN Walisongo tersebut memiliki pertimbangan mengenai fokus pada penyediaan mata kuliah yang secara langsung berkontribusi terhadap pencapaian learning outcomes (Capaian Pembelajaran Lulusan/ CPL). Hasil lulusan diharapkan sesuai dengan kriteria yang dicanangkan dalam profil lulusan sesuai dengan visi dan misi dari Prodi tersebut, yakni menjadi "Program Studi Magister Managemen Pendidikan Islam Riset Unggul Berbasis Kesatuan Ilmu untuk Kemanusiaan dan Peradaban Tingkat ASEAN Tahun 2025".44 Di dalam Permendikbud RI Nomor 73 Tahun 2013 pasal 10 ayat 4 dinyatakan bahwa setiap program studi wajib menyusun kurikulum, melaksanakan, dan mengevaluasi pelaksanaan kurikulum mengacu pada KKNI bidang pendidikan tinggi. Jelas bahwa semua perguruan tinggi di Indonesia yang menyelenggarakan program studi harus mengembangkan kurikulum dan menyusun Capaian Pembelajaran dengan menggunakan KKNI sebagai tolok ukurnya. 45

Dengan demikian dalam upaya pengembangan kurikulum ini ditempuh dua strategi yaitu bottom up dan top down. Bottom up yang didapatkan dari pengguna lulusan dan alumni dimana pengguna lulusan sudah cukup puas da alumni memberi masukan empat hal, sedangkan top down berupa pemenuhan standar nasional kurkulum pendidikan tinggi berdasar Kerangka Kualifikasi Nasional Indonesia (KKNI).

\section{Simpulan}

Upaya pengembangan kurikulum Program Study S.2 Manajemen Pendidikan Islam Pascasarjana UIN Walisongo Semarang telah menempuh dua strategi. Yaitu bottom up yang responsive terhadap kebutuhan pasar dengan indikator bahwa pengguna lulusan telah merasa puas dan responsive dengan

44 Tim Penyusun. 2015. Rencana Strategis dan Rencana Operasional Program Magister Management Pendidikan Islam (MPI) Pascasarjana UIN Walisongo Tahun 2015-2019. Semarang: Prodi MPI Pascasarjana UIN Walisongo, h.5.

45 Tim Kurikulum dan Pembelajaran Direktorat Pembelajaran dan Kemahasiswaan. 2014. h.14. 
kebutuhan lulusan itu sendiri. Sedangkan stretegi kedua dengan top down mengikuti standart Nasional Kurikulum Pendidikan Tinggi barbasis Kerangka Kualifikasi Nasional Indonesia (KKNI).

Para pengguna (users) merespons positif dan puas terhadap keberadaan para alumni Pascasarjana UIN Walisongo umumnya menghendaki adanya keharusan perubahan kurikulum. Mereka mengusulkan penyesuaian kurikulum yang ada di Pascasarjana UIN Walisongo dengan dinamika dan perkembangan zaman yang begitu cepat. Hal itu didasarkan pada pengalaman yang harus selalu beradaptasi dengan tuntutan dan kebutuhan di tempat kerja mereka. Seiring dengan perkembangan zaman, masyarakat juga telah mengalami perubahan dan perkembangan yang luar biasa di segala aspek kehidupan termasuk dalam dunia kerja. Usaha terus menerus dapat dilakukan dalam merancang kurikulum Prodi S2 MPI UIN Walisongo agar tetap selaras dengan perkembangan zaman dan agar matching dengan tuntuan pasar.

\section{Daftar Pustaka}

Abdullah, Abdurrahman Salih, t.t. Educational Theory a Qur'anic Outlook. Makkah al-Mukarromah: Umm al-Qura University.

Ach.Tabrani (alumnus Pascasarjana UIN Walisongo yang bekerja sebagai guru PAI di SMPI al-Azhar BSB Semarang), wawancara oleh Muslih bertempat di gedung FITK UIN Walisongo Semarang. Tanggal 28 Juli 2016, jam 10.0011.00 .

Arikunto, Suharsimi dan Lia Yuliana. 2012. Manajemen Pendidikan. Jakarta: Aditya Media.

Bambang Nianto Mulyo (Kepala Sekolah SMAN 3 Semarang), wawancara oleh Muslih bertempat di SMAN 3 Semarang. Tanggal 26 Juli 2016, Jam 09.00-09.29.

Emy Irianingsih (Waka Kurikulum SMAN 3 Semarang), wawancara oleh Muslih bertempat di SMAN 3 Semarang. Tanggal 26 Juli 2016 di SMAN 3, Jam 08.30-09.00.

Hamalik, Oemar. 1987. Pembinaan Pengembangan Kurikulum. Bandung: Pustaka Madina.

Hery Nugroho (alumnus Pascasarjana UIN Walisongo yang bekerja sebagai guru PAI SMAN 3 Semarang), wawancara 
oleh Muslih bertempat di SMAN 3 Semarang. Tanggal 27 Juli 2016, jam $08.30-10.00$.

Khairi (alumnus Pascasarjana UIN Walisongo yang berkerja sebagai guru PAI SMAN 3 Semarang), wawancara oleh Muslih bertempat di SMAN 3 Semarang. Tanggal 29 Juli 2016, jam $10.00-10.30$.

Khalil, Muhammad Ali. t.t. Qamus Tarbiyah, English-Arab. Beirut: Dar al-'Ilm al-Maliyyin.

Langgulung, Hasan. 1987. Asas-Asas Pendidikan Islam. Jakarta: Pustaka Al-Husna.

Langgulung, Hasan. 1986. Manusia dan Pendidikan suatu Analisa Psikologi Pendidikan. Jakarta: Pustaka Al-Husna.

Maskur (alumnus Pascasarjana UIN Walisongo yang berkerja sebagai guru PAI SMAN 3 Semarang), wawancara oleh Muslih bertempat di SMAN 3 Semarang. Tanggal 29 Juli 2016, jam $09.30-10.00$.

Moleong, J. Lexy. 2006. Metodologi Penelitian Kualitatif. Bandung: Remaja Rosdakarya.

Mulyasa, E. 2006. Kurikulum Tingkat Satuan Pendidikan;

Sebuah Panduan Praktis. Bandung: PT. Remaja Rosdakarya.

Nasution, S. 1989. Kurikulum dan Pengajaran. Jakarta: Rineka Cipta.

Nasution, S. 1991. Pengembangan Kurikulum. Cet. Ke-4, Bandung: Citra Aditya Bakti.

Nasution, S. 2008. Asas-Asas Kurikulum. Jakarta: Bumi Aksara.

Nata, Abudin. 2005. Filsafat Pendidikan Islam. Jakarta: Gaya Media Pratama.

Prodi S2 MPI, 2016. Profil dan Kompetensi Program Studi Program Magister Manajemen Pendidikan Islam (MPI)

Pascasarjana UIN Walisongo, Semarang: UIN Walisongo.

Salim, Peter dan Yenny Salim. 1991. Kamus Bahasa Indonesia Kontemporer. Jakarta: Modern English Press.

Sanjaya, Wina. 2008. Kurikulum dan Pembelajaran, Teori dan Praktek Pengembangan Kurikulum Tingkat Satuan Pendidikan (KTSP). Jakarta: Kencana.

Sugiyono. 2005. Metode Penelitian Pendidikan. Bandung, Alfabeta. 
Sukmadinata, Nana S. 2008. Pengembangan Kurikulum: Teori dan Praktek. Remaja Rosdakarya: Bandung.

Syaibany, Omar Muhammad al-Toumy al-. 1979. Falsafah alTarbiyah al-Islamiyah. terj. Hasan Langgulung. Jakarta: Bulan Bintang.

Tafsir, Ahmad. 2010. Ilmu Pendidikan Islam Dalam Perspektif Islam. Bandung: Remaja Rosdakarya.

Tim Kurikulum dan Pembelajaran Direktorat Pembelajaran dan Kemahasiswaan. 2014. Buku Kurikulum Pendidikan Tinggi. Jakarta: Direktorat Pembelajaran Dan Kemahasiswaan Direktorat Jenderal Pendidikan Tinggi Kementerian Pendidikan Dan Kebudayaan.

Tim Penyusun. 2008. Buku Panduan Pengembangan Kurikulum Berbasis Kompetensi Pendidikan Tinggi (Sebuah alternatif penyusunan kurikulum). Jakarta: Direktorat Akademik Direktorat Jenderal Pendidikan Tinggi.

Tim Penyusun. 2015. Rencana Strategis dan Rencana Operasional Program Magister Management Pendidikan Islam (MPI) Pascasarjana UIN Walisongo Tahun 20152019. Semarang: Prodi MPI Pascasarjana UIN Walisongo.

Tim Penyusun. 2016. Buku Panduan Penyusunan Kurikulum Pendidikan Tinggi. Jakarta: Kementerian Riset, Teknologi Dan Pendidikan Tinggi Direktorat Jenderal Pembelajaran Dan Kemahasiswaan Direktorat Pembelajaran.

Tim Penyusun. 2016c. Profil dan Kompetensi Program Studi Program Magister Management Pendidikan Islam (MPI) Pascasarjana UIN Walisongo. Semarang: Prodi MPI Pascasarjana UIN Walisongo.

Tim Penyusun. 2016d. Company Profil Pascasarjana UIN Walisongo. Semarang: Pascasarjana UIN Walisongo. 